Santamaría-García, Carmen (2014) "Evaluative discourse and politeness in university students' communication through social networking sites". In Geoff Thompson, \& Laura Alba-Juez (eds.) Evaluation in Context. Amsterdam: John Benjamins. 387-411.

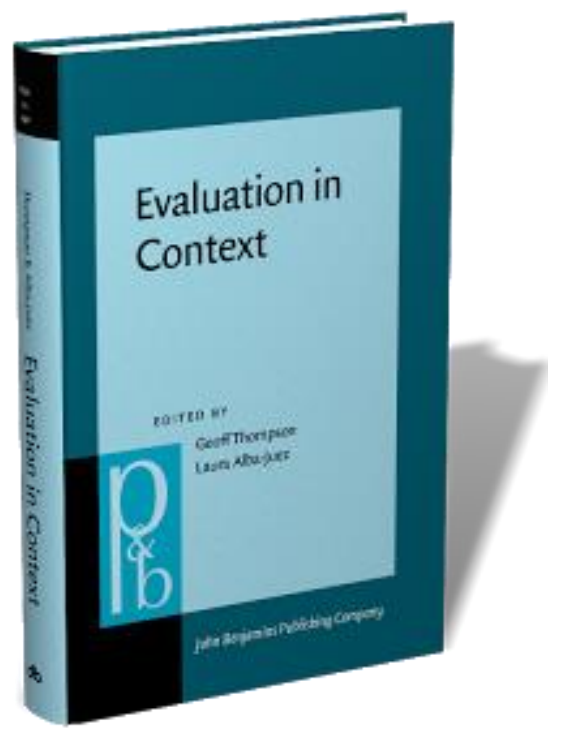

\title{
Evaluative discourse and politeness in university students' communication through social networking sites
}

\author{
Carmen Santamaría-García \\ University of Alcalá, Madrid, Spain
}

\section{PUBLICATION DETAILS:}

Santamaría-García, Carmen (2014) "Evaluative discourse and politeness in university students' communication through social networking sites". In Geoff Thompson, \& Laura Alba-Juez (eds.) Evaluation in Context. Amsterdam: John Benjamins. 387-411.

ISBN 9789027256478

ISBN (e-book) 9789027270726

DOI: $10.1075 /$ pbns.242.19san 
Santamaría-García, Carmen (2014) "Evaluative discourse and politeness in university students' communication through social networking sites". In Geoff Thompson, \& Laura Alba-Juez (eds.) Evaluation in Context. Amsterdam: John Benjamins. 387-411.

\section{Abstract}

This article explores evaluative discourse on social networking sites (henceforth SNSs), paying special attention to the important role played by the expression of attitude and positive politeness in the management of interpersonal rapport. The specific contextual features of SNSs seem to trigger the production of attitudinal meanings of affect, judgement and appreciation, which are exploited for the relational work involved in the construction and maintenance of positive face. The corpus for the study consists of a random sample of 100 messages with 248 evaluative utterances exchanged among university students in the United Kingdom and the United States on a particular site, i.e., Facebook, during the two-year period 2010-2012. Analysis of evaluative discourse is approached from the theories of appraisal (Martin and White 2005, Bednarek 2008) and politeness (Brown and Levinson 1987). The methodology for processing the data borrows quantitative techniques from Corpus Linguistics (CL), involving the coding and statistical treatment of the sample with UAM Corpus Tool (O'Donnell 2011).

Key words: internet-mediated interaction, politeness, appraisal, evaluation.

\section{Introduction and aims of the study}

Social networking sites can be distinguished, as Yus (2011: 11) suggests, from other social networks on the internet as "a sub-group of all the possible scenarios available for Internet-sustained social networks." They offer distinctive features such as the display of pictures and personal data at users' profiles, prompts such as the "what's on your 
Santamaría-García, Carmen (2014) "Evaluative discourse and politeness in university students' communication through social networking sites". In Geoff Thompson, \& Laura Alba-Juez (eds.) Evaluation in Context. Amsterdam: John Benjamins. 387-411.

mind" question or the "like" button and the possibility either to send text or chat messages to selected addressees only or simultaneously to all the contacts (labeled friends) on a public wall. The page layout makes this information easily available and visible while communication is taking place, which stimulates a dialogic orientation towards the interactional and the interpersonal, as will be discussed when commenting on the distinctive features of SNSs in section 3.

The possibilities offered by SNSs have changed the way students interact for doing relational work. They no longer need to use the phone or share the same physical context with other students in order to engage in informal chat with their community because technology has provided other means for interaction. Internet-mediated interaction (IMI) has become a common means for everyday casual communication among students all over the world, at least in those areas where internet-connected computers are easily accessible. The increasing use of last generation cell phones, which feature applications for SNSs, is also motivating students' constant connection and availability through these sites. They even seem to prefer IMI to face-to-face interaction for some communicative purposes. A survey conducted by Yus (2011: 7) shows that $55.3 \%$ in a group of 56 students at lower secondary education think that virtual interaction presents advantages over face-to-face interaction, such as more freedom for expression, due to the fact that they are freed from their physical appearance and from the consequences of the immediate physical reaction of addressees.

Leaving students' preferences and the factors related to them aside, the aim herein is to explore the use of evaluation and its connection with politeness strategies in the discourse of SNSs for the management of interpersonal rapport. The specific features of SNSs will also be explored in order to explain the reasons underlying users' motivation for their choice of evaluation and politeness resources. Evaluation is used as 
Santamaría-García, Carmen (2014) "Evaluative discourse and politeness in university students' communication through social networking sites". In Geoff Thompson, \& Laura Alba-Juez (eds.) Evaluation in Context. Amsterdam: John Benjamins. 387-411.

"the broad cover term for the expression of the speaker or writer's attitude or stance towards, viewpoint on, or feelings about the entities or propositions that he or she is talking about" (Thompson and Hunston 2000: 5). Rapport management is used to refer to "the management of interpersonal relations: the use of language to promote, maintain or threaten harmonious social relations", following Spencer-Oatey (2000: 3). In order to achieve the stated aim, the occurrences of evaluation and politeness strategies in the data will be identified and described, considering whether and how these choices are motivated by the IMI context of SNSs.

\section{Theoretical framework: politeness and appraisal theory}

The framework used for this study benefits from the combination of politeness and appraisal theories. A justification for their relevance will be summarised below.

Politeness theory, as developed by Brown and Levinson (1987), has provided a useful theoretical framework for the study of the management of face and interpersonal rapport. Even when it has been further developed in a more discursive approach in works such as Watts, Ide, and Ehlich (2005) or Lakoff and Ide (2005) and severely criticised (e.g., Eelen 2001, Watts 2003, Mills 2003, Locher and Watts 2005), critiques have not destroyed the model but triggered new trends in research in theoretical, descriptive, comparative and historical perspectives (such as Lakoff and Ide 2005 or Spencer-Oatey 2000). Politeness theory will be used here in order to account for various aspects underlying the evaluative function of language and how it is exploited for the management of face and interpersonal rapport. The connection of evaluation with politeness addresses a need already pinpointed by Channell (2000: 55): “The whole area 
Santamaría-García, Carmen (2014) "Evaluative discourse and politeness in university students' communication through social networking sites". In Geoff Thompson, \& Laura Alba-Juez (eds.) Evaluation in Context. Amsterdam: John Benjamins. 387-411.

of evaluative language seems to require tying up with the notion of 'facework' employed by Brown and Levinson (1987) in their explanation of politeness." This observation motivated my research, connecting both theories, i.e. politeness and appraisal, in order to find out how attitudinal meanings and politeness strategies are combined for the expression of evaluation while doing relational work. The concept of face is central for an understanding of the processes involved in such work. Brown and Levinson (1987: 61) borrowed the concept from Goffman (1967) and defined it as "the public self-image that every member wants to claim for himself." They made a distinction between negative and positive face. Negative face is "the basic claim to territories, personal preserves, rights to non-distraction - i.e. to freedom of action and freedom from imposition", whereas positive face includes "the desire that this selfimage be appreciated and approved of" (Brown and Levinson 1987: 61). Speakers may choose to produce positive politeness strategies, "oriented toward the positive face of Hearer" or negative politeness strategies “oriented mainly toward partially satisfying (or redressing) H's negative face" (Brown and Levinson 1987: 70). In the context of SNSs we can expect users to give priority to their friends' and their own needs for positive face because establishing and maintaining relationships requires of various social skills matching positive politeness strategies, such as claiming common ground, conveying cooperation and fulfilling hearer's wants. Positive politeness will be, therefore, the focus of this study, including the strategies and substrategies briefly summarised in table (1).

“@@ Insert SAN-TABLE-1 here”

Positive Politeness Strategies 
Santamaría-García, Carmen (2014) "Evaluative discourse and politeness in university students' communication through social networking sites". In Geoff Thompson, \& Laura Alba-Juez (eds.) Evaluation in Context. Amsterdam: John Benjamins. 387-411.

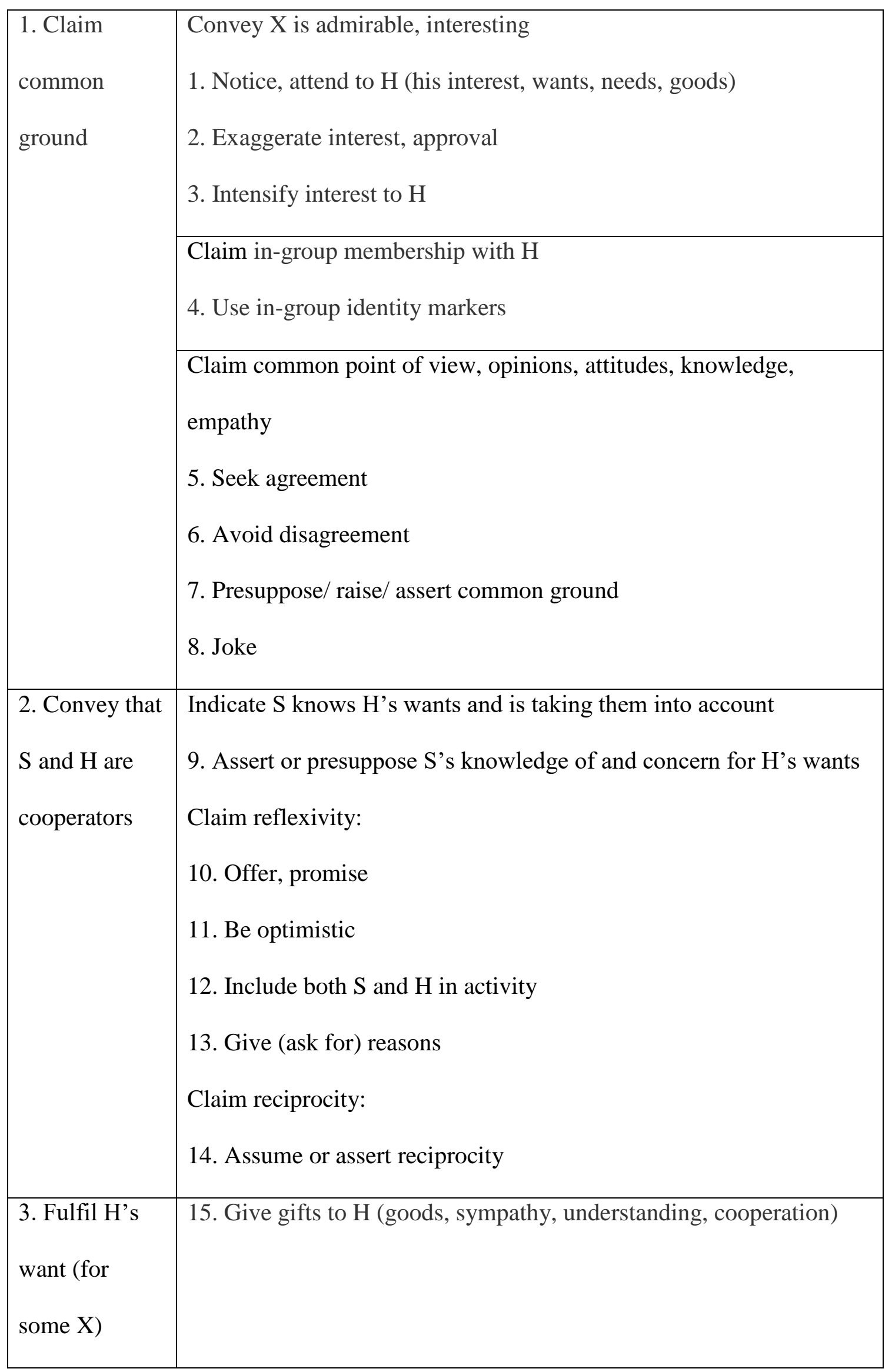


Santamaría-García, Carmen (2014) "Evaluative discourse and politeness in university students' communication through social networking sites". In Geoff Thompson, \& Laura Alba-Juez (eds.) Evaluation in Context. Amsterdam: John Benjamins. 387-411.

Table 1. Positive politeness strategies according to Brown and Levinson (1987: 102).

Appraisal is the system for the expression of evaluation developed by Martin and White (2005) within the framework of Hallidayan Systemic Functional Linguistics (SFL), (Halliday (2004 [1994/1985]). Their model shares many concerns with the work on evaluation by Thompson and Hunston (2000), who distinguish three main functions of evaluation, i.e. expressing opinion, maintaining relations and organizing the discourse. These functions can be seen to be performed for the construction of communities of friends in the data collected from SNSs. While friends use evaluation for expressing opinions they are building a "communal value-system" (Thompson and Hunston 2000: 6) which will have as a result, the construction and maintenance of relations. It is also of interest to mention here the potential of evaluation to persuade or manipulate the reader (as observed by Carter and Nash 1990 or Hoey 2000). Persuasion of friends through evaluation may result in a common way of interpreting reality and hence, in keeping a community together. Martin and White (2005) observe as concerns for appraisal theory "the construction by texts of communities of shared feelings and values, and (...) the linguistic mechanisms for the sharing of emotions, tastes and normative assessments" (2005: 1), concerns shared by this study on how texts construct communities of friends on SNSs. Appraisal resources include attitude, (for the expression of meanings of affect, judgement, and appreciation), together with engagement and graduation resources, used "for adopting a position with respect to propositions and for scaling intensity or degree of investment respectively" (Martin and White 2005: 39). Affect, judgement and appreciation are the three regions of attitude concerned, respectively, with "our feelings, including emotional reactions, judgements of behaviour and evaluation of things" (Martin and White 2005: 35). As 
Santamaría-García, Carmen (2014) "Evaluative discourse and politeness in university students' communication through social networking sites". In Geoff Thompson, \& Laura Alba-Juez (eds.) Evaluation in Context. Amsterdam: John Benjamins. 387-411.

Martin (2000: 147) explains, "In a general sense, affect, judgement and appreciation all encode feeling". Affect is taken as "the basic system", which is then "institutionalized" as judgement or "feelings as proposals (about behaviour) or as appreciation, or "feelings as propositions (about things)", using Halliday's terms. Engagement deals with "sourcing attitudes and the play of voices around opinions in discourse," while graduation "attends to grading phenomena whereby feelings are amplified and categories blurred" (Martin and White 2005: 35). See table (2) for an overview of appraisal resources.

“@@ Insert SAN-TABLE-2 here”

\begin{tabular}{|c|c|c|}
\hline \multicolumn{3}{|c|}{ Appraisal } \\
\hline \multirow[t]{2}{*}{ Engagement } & Monogloss & \\
\hline & Heterogloss & \\
\hline \multirow[t]{3}{*}{ Attitude } & Affect & $\begin{array}{l}\text { Happiness/ unhappiness, } \\
\text { In/security, Satisfaction/ } \\
\text { dissatisfaction, Surprise }\end{array}$ \\
\hline & Judgement & $\begin{array}{l}\text { Social esteem (normality, } \\
\text { capacity, tenacity) } \\
\text { Social sanction (veracity, } \\
\text { propriety) }\end{array}$ \\
\hline & Appreciation & $\begin{array}{l}\text { Reaction, Composition, } \\
\text { Valuation }\end{array}$ \\
\hline \multirow[t]{2}{*}{ Graduation } & Force & Raise \\
\hline & & Lower \\
\hline
\end{tabular}


Santamaría-García, Carmen (2014) "Evaluative discourse and politeness in university students' communication through social networking sites". In Geoff Thompson, \& Laura Alba-Juez (eds.) Evaluation in Context. Amsterdam: John Benjamins. 387-411.

\begin{tabular}{|l|l|l|}
\hline & Focus & Sharpen \\
\cline { 3 - 3 } & & Soften \\
\hline
\end{tabular}

Table 2. Overview of appraisal resources. Adapted from Martin and White (2005: 38) and including surprise as a distinct category for affect (Bednarek 2008: 161).

This paper will focus on attitude (including meanings of affect, judgement, and appreciation), leaving the study of engagement and graduation aside, because the main interest here is to explore the role played by the expression of attitude and its relationship with politeness strategies. Therefore, the tuning of voices or the graduation of their intensity will fall out of scope but may help to give a more detailed picture of appraisal resources in future research. The category of affect will be explored by realisations of happiness/ unhappiness, in/security, satisfaction/ dissatisfaction and other feelings that can be associated with them and are included in the inventory by Martin and White (2005: 48-51) and in the modifications by Bednarek (2008: 142-182), who adds the meaning of surprise as a different category. I have followed Martin and White's inventories (2005: 52-58) for categories of judgement including social esteem (normality, capacity, tenacity) or social sanction (veracity, propriety) and for the categories of appreciation (reaction, composition, valuation).

When taking a close look at real data, I found some practical problems in applying the categories in the appraisal model. One of the most recurrent difficulties, was related to indirectness and has been observed by Thompson (2011): “(...) an expression of one category of appraisal may function as a token (an indirect expression) of a different category; and that token may itself function as an indirect expression of yet another category, and so on." He argues for a coding system which includes 
Santamaría-García, Carmen (2014) "Evaluative discourse and politeness in university students' communication through social networking sites". In Geoff Thompson, \& Laura Alba-Juez (eds.) Evaluation in Context. Amsterdam: John Benjamins. 387-411.

information on the different component categories. For example, an expression of appreciation which can be read as a token expressing judgement, can be coded as "tjudgement [appreciation]." As a result from his observation, I decided to incorporate tags for indirect realisations of attitude in the coding system for the mark up of the data.

I would also like to suggest the need for the inclusion of emoticons as a way of portraying emotions, or affect, which has not been previously discussed in the above mentioned models of appraisal (cf. Bednarek 2008: 150). Emoticons are the representation of facial expressions which can be related to mental disposition terms expressing emotional reactions such as happiness, sadness, anger, etc. They seem to function as signals of facial expressions by signalling the emoter's emotional reactions and could work the same way as interjections and facial expressions do, according to Wharton (2009: 14), by encouraging the hearer "to construct a higher level explicature". The choice of emoticons will depend on the mental disposition of the emoter and can be interpreted by a process of explicature together with the meaning derived from a particular co-text and context. For example, an utterance followed by a sad face such as "Oh, no :-()", which was expressed as a reaction to the destruction caused by Hurricane Irene, can be interpreted, and hence classified in my analysis, as "affect-dissatisfactiondispleasure", communicating an emotional reaction and mental disposition of sadness. Without this emoticon, "Oh, no" could be classified, instead, as "appreciation-reactionnegative impact", expressing a feeling as a proposition "about things", (using Halliday's terms, as quoted by Martin 2000: 147), instead of an emotional reaction by the speaker. The different possibilities of analysis for this example illustrate the subjective nature of the decisions that must be undertaken in the process of categorisation, due to the "fuzzy nature of emotion lexis" (Bednarek 2008: 152). 
Santamaría-García, Carmen (2014) "Evaluative discourse and politeness in university students' communication through social networking sites". In Geoff Thompson, \& Laura Alba-Juez (eds.) Evaluation in Context. Amsterdam: John Benjamins. 387-411.

From this procedural account on the interpretation of emoticons, it follows that emoticons function by triggering a meaning subsumed under the core category of affect, recontextualizing meanings of judgement and appreciation as emotional reactions and giving this character even to utterances with no apparent expression of affect, such as "I’m here :)", which adds happiness to a proposition.

\section{Data and method}

The corpus for analysis consists of a random sample of 100 messages, containing 248 evaluative utterances (1,414 words based on a UAM Corpus Tool count, ignoring the names of the users), which have been circulating among university students in the United Kingdom and the United States through a particular SNS, i.e., Facebook, during the two-year period 2010-2012. I have collected data as a natural observer of the interaction among either friends or friends of friends in my contact list. In order to conform to ethical considerations, I only selected messages made public on users' walls, the public space visible to all friends, and asked them later for permission to use their messages for my research. I also sent them a copy of this article, in order to both guarantee their permission and check my interpretation of their messages. The modest size of the sample is in line with the "somewhat critical attitude towards large-scale corpus analysis" (Bednarek 2008: 142) due to the qualitative character of SFL. It may be at least enough to illustrate recurrent behaviour among users of SNSs. My aim was not to collect a representative sample of the whole group of SNSs users but to explore particular individuals' discourse on SNSs in an attempt to find out common patterns of 
Santamaría-García, Carmen (2014) "Evaluative discourse and politeness in university students' communication through social networking sites". In Geoff Thompson, \& Laura Alba-Juez (eds.) Evaluation in Context. Amsterdam: John Benjamins. 387-411.

evaluative language that may account for the pervasiveness of appraisal resources on SNSs. After all, it is the actions of individual members which contribute to those of the groups. As Eelen (2001: 145) points out: “(..) groups as such do not act, only their individual members do. So, in the end even the most extremely 'socio'-oriented framework needs to say something about individual behavior."

The methodology for collecting, describing and marking up data for analysis has combined quantitative and qualitative techniques together with concepts from Corpus Linguistics (CL), Conversation Analysis (CA) and Discourse Analysis (DA), which have been connected in "a bricolage process of producing a suitable method of analysis”, quoting Denzin and Lincoln (1994: 2) as discussed in Santamaría-García (2011: 346). Marking up of categories with UAM Corpus Tool (O’Donnell 2011) has facilitated their automatic retrieval and exploration for statistical results. CA has been used for the description of interaction units in the corpus at the levels of turn, pair, and sequence. Sinclair and Coulthard's (1975) model for DA together with Tsui's (1994) taxonomy of discourse acts have guided the analysis of acts, moves and exchanges together with their segmentation in initiations, responses or follow ups, which have been further classified into types and subtypes of acts (elicitations, informatives, requestives, etc.).

The mark up of the corpus includes tags for politeness and appraisal, starting with the categories presented in tables (1) and (2) but incorporating subcategories for appraisal following Martin and White (2005), Bednarek (2008) and Thompson (2011). Therefore, the data has been tagged with categories related to the following: 
Santamaría-García, Carmen (2014) "Evaluative discourse and politeness in university students' communication through social networking sites". In Geoff Thompson, \& Laura Alba-Juez (eds.) Evaluation in Context. Amsterdam: John Benjamins. 387-411.

1. Politeness strategies, following Brown and Levinson (1987) for positive and negative strategies and substrategies.

2. Appraisal categories in Martin and White (2005), Bednarek (2008) and Thompson (2011) for attitude: affect, judgement, appreciation and subcategories within them.

The mark-up in the corpus can be illustrated with example (1), containing a tagged segment which is followed by an explanation for its analysis.

(1) File 09/11, (UK)

(a) Last day of the hols! :0(

<Exchange: Initiation> < Discourse act: Expressive> <Affect:

Dissatisfaction, displeasure $><$ Positive politeness: In-group identity markers (Affective language, abbrevation + Emoticon)>

(b) Dislike button needed :o(

$<$ Exchange: Response $><$ Discourse Act: Request + Expressive $><$ Affect: Dissatisfaction, displeasure $><$ Positive politeness: In-group identity markers (Emoticon) + Joke>

In the exchange initiation in (1) the first user produces an expressive act with an evaluative span of affect of the dissatisfaction, displeasure type. This meaning is derived by the combination of "Last day of the hols!" with an emoticon for a sad face. The emoticon portrays an emotion of frustration by the participant, which would not be portrayed in "Last day of the hols!." Without the emoticon, this utterance could be analysed as "appreciation of negative reaction" because the emotional reaction would 
Santamaría-García, Carmen (2014) "Evaluative discourse and politeness in university students' communication through social networking sites". In Geoff Thompson, \& Laura Alba-Juez (eds.) Evaluation in Context. Amsterdam: John Benjamins. 387-411.

appear attached to the entity (day) as a property (last) and detached from the feeling of the human participant. Regarding politeness, the act contains affective markers of "ingroup identity" for positive politeness, realised by the abbreviation "hols" for "holidays" and by an emoticon. User 2 replies with an expressive request showing dissatisfaction of the displeasure type, which is marked for positive politeness with an emoticon and a touch of humour, as this user expresses his reaction by adhering to FB users' movement requesting for a dissatisfaction, "I don't like this" button.

The formulation of hypotheses for this study combine politeness and appraisal theories under the guide of CA methodology, with an interest in discovering possible phenomena and practices in the data, in order to establish evidence that there is a participant-relevant practice. According to my experience as a participant observer on SNSs, I expect users in the corpus to make very frequent use of positive politeness strategies realised by means of appraisal resources for the construction of communities of shared feelings and values. More specifically, the expectation is that users will exchange expressions of affect, with a higher frequency than appreciation or judgement, as realisations of positive politeness strategies, which will contribute to build rapport and solidarity in their communities. On the other hand, I do not expect many occurrences of negative politeness strategies, due to the fact that students do not have as a priority the preservation of their territories, which are already preserved at the safe comfort zones behind their computers. Needless to say, there may be situations of bullying and abuse on SNSs in which students' personal territories can be seriously threatened. However, in this study I will not consider cases of abuse and will only make reference to interaction in communities of friends. 
Santamaría-García, Carmen (2014) "Evaluative discourse and politeness in university students' communication through social networking sites". In Geoff Thompson, \& Laura Alba-Juez (eds.) Evaluation in Context. Amsterdam: John Benjamins. 387-411.

\section{Distinctive features of SNSs that facilitate the production of appraisal and} positive politeness

The exploration of some of the distinctive features of SNSs in previous work attempting at description of the genre, using Bhatia's (2004) approach, have led to the definition of the communicative purpose of SNSs as the construction of social relations by sharing individuals' stance toward life (Santamaría-García, forthcoming). These distinctive features seem to facilitate and even encourage the production of evaluation and positive politeness for the construction of communities of friends with shared feelings and values. They are summarised below in relation to SNSs' potential to implement the following: (i) Interactional versus transactional function of language, (ii) interpersonal versus ideational meaning, (iii) dialogic orientation.

The interactional function is used "to establish and maintain social relationships" (Brown and Yule 1983: 3), in opposition to the transactional one, used to convey "factual or propositional information" (Brown and Yule 1983: 2). SNSs seem to be taking up the role initially confined to the oral culture (either face-to-face or phone delivered) for establishing and maintaining social relationships. They provide a space for sharing evaluation of real life situations and are, therefore, being used to create a feeling of community through IMI. As Martínez and Wartmann (2009: 4) claim: "Students use these sites to interact and bond with other students, to share experiences, and to participate in the new online college 'community' that is understood by students to be real."

The peculiarity of SNSs, in contrast to other means of oral communication, is that one user can address a whole community of friends at the same time. Friends are a community of contacts who may only be acquaintances but are linked by "positive affective involvement", using the terms provided by Eggins and Slade (1997: 52) to 
Santamaría-García, Carmen (2014) "Evaluative discourse and politeness in university students' communication through social networking sites". In Geoff Thompson, \& Laura Alba-Juez (eds.) Evaluation in Context. Amsterdam: John Benjamins. 387-411.

refer to the dimensions of social identity. Once they get the status of "friend", they tend to behave as such, so as not to lose this condition, which involves doing relational work by making use of appraisal and politeness resources.

(ii) Interpersonal versus ideational meaning.

Once a community of friends is created, interaction will be usually aimed at keeping the friend status, which results in the use of an extensive range of language resources for construing interpersonal meaning, as the manifestation of the purpose "to act on the others" (Halliday, 2004: xiii). Interpersonal deals with "meaning about roles and relationships (e.g. status, intimacy, contact, sharedness between interactants)" (Eggins and Slade 1997: 49). The use of emoticons, and prompts, such as the "what is on your mind" question or the "like" button invite users to express their attitude which will invite other users' contributions, contributing to the building of rapport and solidarity. This happens because, as Martin and White (2005: 95) observe: “(...) when speakers/writers announce their own attitudinal positions they not only self-expressively 'speak their own mind', but simultaneously invite others to endorse and to share with them the feelings, tastes or normative assessments they are announcing." It seems that FB designers have made the same observation and have introduced prompts that stimulate engagement through the expression of attitude.

(iii) Dialogic frame.

One of the most significant features of SNSs that also seems to be responsible for their increasing success is their implementation of a dialogic frame, which facilitates dialogue between users and their communities, even when the individuals are not engaged in the dialogic activity simultaneously. The wall keeps and shows the latest contributions of our friends creating a "heteroglossic" framework of different voices. Whereas writing has typically been an asynchronous communication mode with 
Santamaría-García, Carmen (2014) "Evaluative discourse and politeness in university students' communication through social networking sites". In Geoff Thompson, \& Laura Alba-Juez (eds.) Evaluation in Context. Amsterdam: John Benjamins. 387-411.

addressees out of sight, SNSs bridge the gap between writing and speech to some extent. Friends are visible by means of pictures and we are even told whether they are connected at the same time, therefore facilitating their presence in our minds and dialogues. Moreover, the creation of a socially significant community of friends with shared knowledge stimulates dialogue and facilitates engagement among users. Facebook facilitates this process of sharing contextual information by providing the option to send the location of users and to inform about their presence at several public places automatically. For instance: "David has just checked in at Munich airport" or "David has been at Russell Hotel." Comments on the activities are still the responsibility of individuals: "BEST. WEEK. EVER!" (stops and capitals in original), "Having teeth out is poo:(." However, the expression of evaluation is also facilitated by the "like" button, which can be clicked to express a quick and automatic dialogic engagement of users, (Santamaría-García forthcoming). This button also seeks agreement, a politeness strategy which serves to "claim common point of view, opinions, attitudes, knowledge, empathy" (Brown and Levinson 1987: 102). It may serve to express different meanings, as can be illustrated with some examples. Generally speaking, this prompt is an invitation to react to anything previously said and acts as an emotional trigger, motivating the users' expressions of attitude. "I like this" can be interpreted as affect, judgement, or appreciation, depending on the context. In the following example, the fact that (b) likes a summons for help in an area devastated after the effects of Hurricane Irene, can be taken as a token of judgement, evaluating the action of helping as good behavior.

(2) FILE 09/11, (US) 
Santamaría-García, Carmen (2014) "Evaluative discourse and politeness in university students' communication through social networking sites". In Geoff Thompson, \& Laura Alba-Juez (eds.) Evaluation in Context. Amsterdam: John Benjamins. 387-411.

(a) Hi Everybody. Please read this. Your help is needed with the clean-up from the floods that ravaged Schoharie and Greene counties from Irene. YOUR help. The time is not later, it is now. Willing to give some time?

Call Sarah Goodrich, who is coordinating volunteers in the town of Schoharie, 518.470.0014

(b) "Like" button.

Users may combine the automatic click with free language use. For example, in the following exchange, (b) expresses affect of satisfaction, pleasure types towards (a)'s comment by clicking the "like" button and by adding "YES YES YES!."

(3) FILE 1/11 (2), (UK)

(a) strokes are gonna tour the UK in july pal. we are there!! $\mathrm{x}$

(b) ("Like" button) YES YES YES!

The "like" button together with emoticons for facial expressions also prove useful resources for the construction of solidarity, as allies of the two principles on which solidarity is constructed according to appraisal theory, i. e. proliferation and contraction, (Martin and White 2005: 29). Proliferation "refers to the idea that the closer you are to someone, the more meanings you have available to exchange" and contraction "refers to the amount of work it takes to exchange meanings, and the idea that the better you know someone the less explicitness it takes" (Martin and White 2005: 30-31). When you are close to someone, according to these principles, you may even not say anything, but use simply a smile or any other body gesture to show attitude, and you will be properly understood. On SNSs, you may even not say 
Santamaría-García, Carmen (2014) "Evaluative discourse and politeness in university students' communication through social networking sites". In Geoff Thompson, \& Laura Alba-Juez (eds.) Evaluation in Context. Amsterdam: John Benjamins. 387-411.

anything, but use an emoticon or click the "like" button and be contributing to build solidarity, by virtue of the principles of proliferation and contraction.

Thus, from this review of features, it seems that the use of language on SNSs for the interactional and interpersonal, together with a dialogic frame that allows for simultaneous communication with many addressees connected by positive affective involvement, can be held responsible for the frequent use of evaluation and positive politeness, as resources for building rapport and solidarity in the community. The reviewed features may also explain the "overabundance" of politeness resources and can be added to the "absence of contextual cues", observed by Yus (2011: 275) as an explanation: "On the Internet, there is an absence of contextual cues that normally facilitate, in physical environments, the choice of a particular (im)polite strategy. This may lead to an overabundance of overt expressions of politeness."

\section{Results: appraisal and positive politeness in the construction of communities of shared feelings and values}

Analysis of the data attempts to show the connection between the special features of SNSs, described in the previous section, and the use of politeness and evaluation, looking for evidence supporting the hypotheses of this study. The results show that appraisal resources are exploited mainly for the expression of affect together with positive politeness. Affect is produced more frequently than judgement and appreciation. It is present in $64.11 \%(\mathrm{n}=159)$, of the total number of evaluative utterances $(\mathrm{n}=248)$ containing attitude, while judgement features in $21.77 \%(\mathrm{n}=54)$ and 
Santamaría-García, Carmen (2014) "Evaluative discourse and politeness in university students' communication through social networking sites". In Geoff Thompson, \& Laura Alba-Juez (eds.) Evaluation in Context. Amsterdam: John Benjamins. 387-411.

appreciation in $14.11 \%(\mathrm{n}=35)$. Table (3) presents the results for the analysis of different types of attitude.

“@@ Insert SAN-TABLE-3 here”

\begin{tabular}{|c|c|c|}
\hline \multirow{2}{*}{ Attitude-type } & Percentage & $\mathrm{N}$ \\
\hline & \multicolumn{2}{|r|}{$\mathrm{N}=248$} \\
\hline Affect & $64.11 \%$ & 159 \\
\hline Judgement & $21.77 \%$ & 54 \\
\hline Appreciation & $14.11 \%$ & 35 \\
\hline
\end{tabular}

Table 3. Results for the analysis of types of attitude

Each of the categories has been further explored into subcategories, showing the results in different tables: (4) for affect, (5) for judgement and (6) for appreciation. Regarding affect, the expression of un/happiness $(48.4 \%, \mathrm{n}=77)$, dis/inclination $(20.8 \%$, $\mathrm{n}=33)$ and dis/satisfaction $(19.5 \%, \mathrm{n}=31)$ are the most frequently produced in the data. Users show a tendency to use SNSs especially for the expression of happiness $(84.4 \%$, $\mathrm{n}=65)$ versus unhappiness $(15.6 \%, \mathrm{n}=12)$ with many expressions for cheering friends $(50.8 \%, \mathrm{n}=33)$ and showing affection $(49.2 \%, \mathrm{n}=32)$ such as "Chin up" or "Free hugs" respectively. Inclination $(20.8 \%, \mathrm{n}=33)$ is used for expressing good wishes for friends (e.g. "It'll settle down soon"), with no instances found for expressing lack of desire. Within the category of dis/satisfaction, satisfaction $(58.1 \%, \mathrm{n}=18)$ is slightly more frequent than dissatisfaction $(41.9 \%, \mathrm{n}=13)$, especially for expressing pleasure $(77.8 \%$, n=14), such as "BEST. WEEK. EVER" or "Glad you are having a fab time."

“@@ Insert SAN-TABLE-4 here” 
Santamaría-García, Carmen (2014) "Evaluative discourse and politeness in university students' communication through social networking sites". In Geoff Thompson, \& Laura Alba-Juez (eds.) Evaluation in Context. Amsterdam: John Benjamins. 387-411.

\begin{tabular}{|c|c|c|}
\hline Affect & Percentage & $\mathrm{N}$ \\
\hline Affect-type & $\mathrm{N}=159$ & \\
\hline un/happiness & $48.4 \%$ & 77 \\
\hline dis/satisfaction & $19.5 \%$ & 31 \\
\hline in/security & $6.9 \%$ & 11 \\
\hline dis/inclination & $20.8 \%$ & 33 \\
\hline surprise & $4.4 \%[$ & 7 \\
\hline Affect-1-type & $\mathrm{N}=77$ & \\
\hline happiness & $84.4 \%$ & 65 \\
\hline unhappiness & $15.6 \%$ & 12 \\
\hline Happiness-type & $\mathrm{N}=65$ & \\
\hline cheer & $50.8 \%$ & 33 \\
\hline affection & $49.2 \%$ & 32 \\
\hline Unhappiness-type & $\mathrm{N}=12$ & \\
\hline misery & $100.0 \%$ & 12 \\
\hline antipathy & $0.0 \%$ & 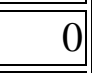 \\
\hline Affect-2-type & $\mathrm{N}=31$ & \\
\hline satisfaction & $58.1 \%$ & 18 \\
\hline dissatisfaction & $41.9 \%$ & 13 \\
\hline Satisfaction-type & $\mathrm{N}=18$ & \\
\hline interest & $22.2 \%$ & 4 \\
\hline pleasure & $77.8 \%$ & 14 \\
\hline Dissatisfaction-type & $\mathrm{N}=13$ & \\
\hline ennui & $0.0 \%$ & 0 \\
\hline displeasure & $100.0 \%$ & 13 \\
\hline In/security-type & $\mathrm{N}=11$ & \\
\hline security & $18.2 \%$ & 2 \\
\hline insecurity & $81.8 \%$ & 9 \\
\hline Security-type & $\mathrm{N}=2$ & \\
\hline quiet_ & "0.0\% & 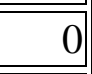 \\
\hline trust & $100.0 \%$ & 2 \\
\hline Insecurity-type & $\mathrm{N}=9$ & \\
\hline disquiet & $100.0 \%$ & 9 \\
\hline distrust & $0.0 \%$ & 0 \\
\hline Dis/inclination-type & $\mathrm{N}=33$ & \\
\hline inclination/desire & $100.0 \%$ & 33 \\
\hline disinclination/non-desire & $0.0 \%$ & 0 \\
\hline
\end{tabular}


Santamaría-García, Carmen (2014) "Evaluative discourse and politeness in university students' communication through social networking sites". In Geoff Thompson, \& Laura Alba-Juez (eds.) Evaluation in Context. Amsterdam: John Benjamins. 387-411.

Table 4. Realisation of affect in the data.

Analysis of judgement reveals that the expression of social sanction $(60.4 \%$, $\mathrm{n}=32)$ is more frequent than the expression of social esteem $(39.6 \%, \mathrm{n}=21)$. In the sample, the expression of social sanction of propriety features highly $(68.8 \%, \mathrm{n}=22)$ as a means to express and negotiate what counts as appropriate behavior in the community: "How very corporate, Jen." It is used mainly for positive praise of friends' behaviour $(65.0 \%, n=13)$. Negative condemnation features lower $(30 \%, n=6)$ and refers to third parties. This is an example of the latter, criticising the behavior of an Indian rich man on a news report article: "And he says he 'bleeds for India' and he wants to help pave the way for a better life for the country's poor...hey, he could have probably fed half of India with what he spent on this little house...." Regarding social esteem, tenacity $(57.1 \%, \mathrm{n}=12)$ is the most frequent category, as friends usually comment on their plans and what they have decided to do and are doing at the moment: "I'm also helping to collect school supplies."

“@@ Insert SAN-TABLE-5 here”

\begin{tabular}{|l|l|l||}
\hline Judgement & Percent & N \\
\hline Judgement-type & $\mathrm{N}=53$ & 21 \\
\hline \hline Social-esteem & $39.6 \%$ & 32 \\
\hline Social-sanction & $60.4 \%$ & $\mathrm{~N}=21$ \\
\hline \hline nocial-esteem & $4.8 \%$ \\
\hline
\end{tabular}


Santamaría-García, Carmen (2014) "Evaluative discourse and politeness in university students' communication through social networking sites". In Geoff Thompson, \& Laura Alba-Juez (eds.) Evaluation in Context. Amsterdam: John Benjamins. 387-411.

\begin{tabular}{|c|c|c|}
\hline |capacity & $38.1 \%$ & 8 \\
\hline tenacity & $57.1 \%$ & 12 \\
\hline Normality-type & $\mathrm{N}=1$ & \\
\hline positive-normality-admire & $100.0 \%$ & 1 \\
\hline negative-normality-criticise & $0.0 \%$ & 0 \\
\hline Capacity-type & $\mathrm{N}=6$ & \\
\hline positive-capacity-admire & $33.3 \%$ & 2 \\
\hline negative-capacity-criticise & $50.0 \%$ & 3 \\
\hline question-implicit-capacity & $16.7 \%$ & 1 \\
\hline Tenacity-type & $\mathrm{N}=11$ & \\
\hline positive-tenacity-admire & $90.9 \%$ & 10 \\
\hline negative-tenacity-criticise & $9.1 \%$ & 1 \\
\hline Social-sanction-type & $\mathrm{N}=32$ & \\
\hline veracity & $31.2 \%$ & 10 \\
\hline propriety & $68.8 \%$ & 22 \\
\hline Veracity-type & $\mathrm{N}=8$ & \\
\hline positive-praise-truth & $50.0 \%$ & 4 \\
\hline negative-condemn-truth & $37.5 \%$ & 3 \\
\hline question-implicit-praise & $12.5 \%$ & 1 \\
\hline Propriety-type & $\mathrm{N}=20$ & \\
\hline positive-praise-ethics & $65.0 \%$ & 13 \\
\hline
\end{tabular}


Santamaría-García, Carmen (2014) "Evaluative discourse and politeness in university students' communication through social networking sites". In Geoff Thompson, \& Laura Alba-Juez (eds.) Evaluation in Context. Amsterdam: John Benjamins. 387-411.

\begin{tabular}{|l|l||l||}
\hline negative-praise-ethics & $30.0 \%$ & 6 \\
\hline question-implicit-ethics & $5.0 \%$ & 1 \\
\hline
\end{tabular}

Table 5. Realisation of judgement in the data.

Considering appreciation, the categories of reaction $(48.6 \%, n=17)$ and valuation $(34.3 \%, \mathrm{n}=12)$ are the most frequently produced, as shown in table (6). Within reaction, expression of impact $(88.2 \%, \mathrm{n}=15)$ overrides quality $(11.8 \%, \mathrm{n}=2)$ and expression of negative $(86.7 \%, \mathrm{n}=13)$ is more frequent than expression of positive impact $(13.3 \%$, $\mathrm{n}=2)$. However, when valuation is expressed, positive valuation $(63.6 \%, \mathrm{n}=7)$ overrides negative $(36.4, \mathrm{n}=4)$. This means that users tend to choose reaction resources when something produces a negative impact on them (e.g. "It's truly shocking how horrible it is", "it's pretty devastating stuff") while the tendency is to use valuation for positive appreciation ("The good thing about Schoharie is that they are pretty well organized").

“@@Insert SAN-TABLE-6 here”

\begin{tabular}{|c|c|c|}
\hline Appreciation & Percent & $\mathrm{N}$ \\
\hline Appreciation-type & \multicolumn{2}{|l|}{$\mathrm{N}=35$} \\
\hline reaction & $48.6 \%$ & 17 \\
\hline composition & $17.1 \%$ & 6 \\
\hline valuation & $34.3 \%$ & 12 \\
\hline Reaction-type & \multicolumn{2}{|l|}{$\mathrm{N}=17$} \\
\hline impact & $88.2 \%$ & 15 \\
\hline quality & $11.8 \%$ & 2 \\
\hline Impact-type & \multicolumn{2}{|l|}{$\mathrm{N}=15$} \\
\hline positive-impact & $13.3 \%$ & 2 \\
\hline
\end{tabular}


Santamaría-García, Carmen (2014) "Evaluative discourse and politeness in university students' communication through social networking sites". In Geoff Thompson, \& Laura Alba-Juez (eds.) Evaluation in Context. Amsterdam: John Benjamins. 387-411.

\begin{tabular}{|c|c|c|}
\hline negative-impact & $86.7 \%$ & 13 \\
\hline Quality-type & \multicolumn{2}{|l|}{$\mathrm{N}=2$} \\
\hline positive-quality & $100.0 \%$ & 2 \\
\hline negative-quality & $0.0 \%$ & 0 \\
\hline Composition-type & \multicolumn{2}{|l|}{$\mathrm{N}=6$} \\
\hline balance & $33.3 \%$ & 2 \\
\hline complexity & $66.7 \%$ & 4 \\
\hline Balance-type & \multicolumn{2}{|l|}{$\mathrm{N}=2$} \\
\hline positive-balance & $100.0 \%$ & 2 \\
\hline negative-balance & $0.0 \%$ & 0 \\
\hline Complexity-type & \multicolumn{2}{|l|}{$\mathrm{N}=4$} \\
\hline positive-complexity & $0.0 \%$ & 0 \\
\hline negative-complexity & $100.0 \%$ & 4 \\
\hline Valuation-type & \multicolumn{2}{|l|}{$\mathrm{N}=11$} \\
\hline positive-valuation & $63.6 \%$ & 7 \\
\hline negative-valuation & $36.4 \%$ & 4 \\
\hline
\end{tabular}

Table 6. Realisation of appreciation in the data.

Some turns contain a combination of several meanings simultaneously, like the following example, in which (b)'s turn combines (i) affect with the expression of happiness (feeling good), (ii) appreciation, of the type of composition, complexity (hard 
Santamaría-García, Carmen (2014) "Evaluative discourse and politeness in university students' communication through social networking sites". In Geoff Thompson, \& Laura Alba-Juez (eds.) Evaluation in Context. Amsterdam: John Benjamins. 387-411.

work routine), (iii) inclination, (looking forward to teaching), (iv) affection shown by crosses and greetings

(4) FILE 09/11, (UK)

(a) Hello Fee! How are you? How is it getting back at work? hope all is well $\operatorname{xxxxxxx}$

(b) I'm good thanks. Always hard getting back into work routine but looking forward to starting teaching in a couple of weeks $\mathrm{x}$ how's you? X

Example 5 shows two expressions of affect and one of appreciation in a single message: (i) happiness (playful onomatopoeia simulating the ring of a telephone and affective nickname for Fiona), (ii) inclination and disposition ("thinking of you" and an emoticon at the end of the sentence), (iii) an expression of appreciation of positive emotional reaction to Barcelona ("Lovin it"):

(5) FILE 09/11, (UK)

(a): Woop a woo wooo fee fee, thinking of you whilst I'm here in Barcelona! Lovin it, beach an las ramblas today :)

Affect and appreciation are mainly realised directly. There are some exceptions, such as formulae for expressing the feeling of surprise ("I can't believe it", "Oh, no") by means of judgement of veracity. Some appreciations of things can also be read as expressing affect, such as "BEST. WEEK. EVER", which shows the feeling of satisfaction and pleasure of the user and is coded as an indirect expression of affect. The expression of judgement, however, gets more indirect realisations (although only a total 
Santamaría-García, Carmen (2014) "Evaluative discourse and politeness in university students' communication through social networking sites". In Geoff Thompson, \& Laura Alba-Juez (eds.) Evaluation in Context. Amsterdam: John Benjamins. 387-411.

of seven in the data). The following extract shows an instance of an indirect expression of judgement of social esteem related to normality (how unusual someone is) realised by affect ("I don't like"), reacting to other's behaviour and conveying it is odd, peculiar or eccentric:

(6) FILE 09/11, (US)

(a) I like Charlie, don't like your thesis frustration so much. Have a beer!

In the following example, judgement of the same type (social esteem related to normality) is realised by means of appreciation ("School is so difficult. New Head and loads of changes") and by reacting to these difficulties and changes, (a) criticises the new situation at work and the people in charge, who produce a negative effect on her feelings:

(7) FILE 09/11, (UK)

(a) School is so difficult. New head and loads of changes. I'm just miserable. $\mathrm{xx}$

Considering now the realisation of politeness strategies, the results show a high total number, with 181 instances of different positive politeness strategies scattered along the 100 turns in the sample. However, only 2 instances of negative politeness of apologising have been found. "Claim common ground" is the most frequent strategy $(69.1 \%, \mathrm{n}=125)$, especially for claiming common point of view $(48.8 \%, \mathrm{n}=61)$ of the type "presuppose, raise, assert common ground", by means of which friends share the information needed for the construction of a community of feelings and values. For 
Santamaría-García, Carmen (2014) "Evaluative discourse and politeness in university students' communication through social networking sites". In Geoff Thompson, \& Laura Alba-Juez (eds.) Evaluation in Context. Amsterdam: John Benjamins. 387-411.

instance, friends claim common point of view and raise common ground on several issues regarding the best procedure to help the damaged communities after Hurricane Irene: "If you want to help in Schoharie, it's important to get in touch with Sarah Goodrich before you arrive, since parking is difficult and they are trying to stay organized."

Intensification shows the highest percentage of occurrence within "convey $\mathrm{x}$ is interesting" $(63.2 \%, \mathrm{n}=24)$ with the use of intensifiers ("I'm just miserable", I'm so sorry", "She is really smart"), capitalization ("Your help is needed. YOUR help"), phonic lengthening ("Whaaaaat"). The two last examples show proof of gradation in socalled invariable parts of speech, which are becoming variable on IMI.

When considering "convey cooperation", the more frequent substrategy is "taking H's wants into account" (50\%, $n=13)$, which serves the expression of empathy feelings: "Chin up. It'll settle down soon", "You need to take it easy, kiddo".

Fulfilment of H's wants includes expressions of cooperation such as "With you on that, Zemie".

“@@ Insert SAN-TABLE-7 here”

\begin{tabular}{|c|c|c|}
\hline Politeness strategies & Percent & $\mathrm{N}$ \\
\hline Positive-politeness-type & \multicolumn{2}{|c|}{$\mathrm{N}=181$} \\
\hline claim-common-ground & $69.1 \%$ & 125 \\
\hline convey-cooperation & $14.4 \%$ & 26 \\
\hline fulfill-h's-want & $16.6 \%$ & 30 \\
\hline Claim-common-ground-type & \multicolumn{2}{|l|}{$\mathrm{N}=125$} \\
\hline convey-X-is-interesting & $30.4 \%$ & 38 \\
\hline claim-in-group-membership & $20.8 \%$ & 26 \\
\hline claim-common-point-of-view-etc & $48.8 \%$ & 61 \\
\hline
\end{tabular}


Santamaría-García, Carmen (2014) "Evaluative discourse and politeness in university students' communication through social networking sites". In Geoff Thompson, \& Laura Alba-Juez (eds.) Evaluation in Context. Amsterdam: John Benjamins. 387-411.

\begin{tabular}{|c|c|c|}
\hline Convey-x-is-interesting-type & $\mathrm{N}=38$ & \\
\hline 1-notice-attend & $21.1 \%$ & 8 \\
\hline 2-exaggerate & $15.8 \%$ & 6 \\
\hline 3-intensify & $63.2 \%$ & 24 \\
\hline Claim-in-group-membership-type & $\mathrm{N}=25$ & \\
\hline 4-identity-markers & $100.0 \%$ & 25 \\
\hline Claim-common-point-of-view-etc-type & $\mathrm{N}=61$ & \\
\hline 5-seek-agreement & $6.6 \%$ & 4 \\
\hline 6-avoid-disagreement & $3.3 \%$ & 2 \\
\hline 7-raise-assert-common-ground & $80.3 \%$ & 49 \\
\hline 8-joke|| & $9.8 \%$ & 6 \\
\hline Convey-cooperation-type & $\mathrm{N}=26$ & \\
\hline taking-H's-wants-into-account & $50.0 \%$ & 13 \\
\hline claim-reflexivity\| & $38.5 \%$ & 10 \\
\hline claim-reciprocity | & $11.5 \%$ & 3 \\
\hline Taking-H's-wants-into-account-type & $\mathrm{N}=12$ & \\
\hline 9-knowledge-and-concern & $100.0 \%$ & 12 \\
\hline Claim-reflexivity-type & $\mathrm{N}=10$ & \\
\hline 10-offer-promise & $50.0 \%$ & 5 \\
\hline 11-be-optimistic & $20.0 \%$ & 2 \\
\hline 12-inclusion-of- $\mathrm{h}$ & $0.0 \%$ & 0 \\
\hline 13-give-ask-reasons | & $30.0 \%$ & 3 \\
\hline Claim-reciprocity-type & $\mathrm{N}=0$ & \\
\hline 14-reciprocity & $0.0 \%$ & 0 \\
\hline Fulfill-H' s-want-type & $\mathrm{N}=30$ & \\
\hline 15-sympathy,-understanding & $100.0 \%$ & 30 \\
\hline
\end{tabular}


Santamaría-García, Carmen (2014) "Evaluative discourse and politeness in university students' communication through social networking sites". In Geoff Thompson, \& Laura Alba-Juez (eds.) Evaluation in Context. Amsterdam: John Benjamins. 387-411.

\begin{tabular}{|c|c|c|}
\hline Negative-politeness & \multicolumn{2}{|l|}{$\mathrm{N}=2$} \\
\hline don't-impinge & $100.0 \%$ & 2 \\
\hline Don't-impinge-type & \multicolumn{2}{|l|}{$\mathrm{N}=2$} \\
\hline apologise $\|$ & $100.0 \%$ & 2 \\
\hline
\end{tabular}

Table 7. Realisation of politeness in the data. The strategies of positive politeness are preceded by the numbers used by Brown and Levinson (1987: 102).

Exploration for the combination of positive politeness strategies with the expression of attitude, has shown that a very high percentage of the strategies in the data $(96.11 \%, \mathrm{n}=174)$ contain attitude, with the following distribution of categories. Affect is included in $57.45 \%(n=104)$ of the cases (out of the total number of occurrences of politeness strategies, i.e. 181), judgement in $22.09 \%(n=40)$ and appreciation in $16.57 \%$. $(n=30)$. Claiming common ground is the strategy that is more frequently realised by the expression of affect, judgement and appreciation, especially with the function of "presuppose, raise, assert common ground" which serves to inform the community of friends in order to construct a community of shared knowledge.

“@@ Insert SAN-TABLE-8 here”

\begin{tabular}{||l||l|l|l||}
\hline & \multicolumn{3}{|c||}{ Positive politeness strategies $(\mathrm{n}=181)$} \\
\hline \hline Attitude-type & Claim common ground & $\begin{array}{l}\text { Convey that } \mathrm{S} \text { and } \mathrm{H} \\
\text { are cooperators }\end{array}$ & Fulfill H's want \\
\hline Affect & $\mathrm{N}=66$ & $\mathrm{~N}=16$ & $\mathrm{~N}=22$ \\
$\mathrm{~N}=104$ & $63.46 \%$ & $15.38 \%$ & $21.15 \%$ \\
$57.45 \%$ & & & \\
\hline
\end{tabular}


Santamaría-García, Carmen (2014) "Evaluative discourse and politeness in university students' communication through social networking sites". In Geoff Thompson, \& Laura Alba-Juez (eds.) Evaluation in Context. Amsterdam: John Benjamins. 387-411.

\begin{tabular}{|c|c|c|c|}
\hline \begin{tabular}{|l} 
Judgement \\
$\mathrm{N}=40$ \\
$22.09 \%$ \\
\end{tabular} & $\begin{array}{l}\mathrm{N}=28 \\
70 \%\end{array}$ & $\begin{array}{l}\mathrm{N}=7 \\
17.5 \%\end{array}$ & $\begin{array}{l}\mathrm{N}=5 \\
12.5 \%\end{array}$ \\
\hline \begin{tabular}{|l} 
Appreciation \\
$\mathrm{N}=30$ \\
$16.57 \%$ \\
\end{tabular} & $\begin{array}{l}\mathrm{N}=23 \\
76.66 \%\end{array}$ & $\begin{array}{l}\mathrm{N}=3 \\
10 \%\end{array}$ & $\begin{array}{l}\mathrm{N}=4 \\
13.33 \%\end{array}$ \\
\hline $\begin{array}{l}\text { Total } \\
\mathrm{N}=174 \\
96.11 \%\end{array}$ & $\mid \begin{array}{l}N=117 \\
67 \%\end{array}$ & $\begin{array}{l}\mathrm{N}=26 \\
14.94 \%\end{array}$ & $\begin{array}{l}\mathrm{N}=31 \\
17.81 \%\end{array}$ \\
\hline
\end{tabular}

Table 8. Realisation of attitude by means of positive politeness strategies

The high number of positive politeness strategies in the data $(n=181$ in 100 turns) indicates the usefulness of SNSs as a medium in which users can satisfy their need for positive face, fulfilling the three broad mechanisms for positive politeness, i.e. to "Claim common ground", "Convey that S and H are cooperators" and "Fulfil H's want". The results of the analysis of the combination of attitudinal meanings with politeness strategies shows that users of SNSs rely heavily on the expression of attitude (96.11\%) in order to build positive face while doing relational work within their community.

The following fragment from the data attempts to illustrate the correspondence which can be observed between positive politeness strategies and appraisal resources of attitude. Speaker (b)'s turn is analysed according to politeness and appraisal meanings. The strategies are preceded by the numbers used by Brown and Levinson (1987: 102), which were also included in tables (1) and (7).

(8) FILE 09/11, (US)

(a) Summons for help in an area devastated by floods. Also included above in fragment (1) 
Santamaría-García, Carmen (2014) "Evaluative discourse and politeness in university students' communication through social networking sites". In Geoff Thompson, \& Laura Alba-Juez (eds.) Evaluation in Context. Amsterdam: John Benjamins. 387-411.

Hi Everybody. Please read this. Your help is needed with the clean-up from the floods that ravaged Schoharie and Greene counties from Irene. YOUR help. The time is not later, it is now. Willing to give some time?

Call Sarah Goodrich, who is coordinating volunteers in the town of Schoharie, 518.470.0014

(b) I like this. (Click of the "like" button by Eva)

Eva was just there today helping to gut a house. It's pretty devastating stuff. I'm also helping to collect school supplies, which is apparently needed; One of my friends is making another trip up there Monday.

Table (9) shows the realisation of positive politeness with appraisal resources by means of different types of attitude. As a response to the summons for help by user (a), user (b) claims common ground with user (a) and her community of friends. With "I like this", resulting from a click of the "like" button, she is expressing a literal meaning of affect of the satisfaction, pleasure types. She is attending and noticing her addressee's want for positive face by conveying that helping is admirable and interesting (strategy 1). She is also claiming common point of view, opinions, attitudes, knowledge and empathy with user (a), by seeking the agreement of other users' (strategy 5) and by presupposing/raising common ground, i.e. an interest to help (strategy 7), "indicating that $\mathrm{S}$ and $\mathrm{H}$ belong to the same set of persons who share specific wants, including goals and values" (Brown and Levinson 1987: 103). All these meanings are realised by means of "I like it", a literal expression of affect, which, in this context, can be interpreted as a token for judgement of social sanction, showing propriety, i.e. helping is considered to be good behaviour. Likewise, the following utterances in Eva's turn serve her purpose 
Santamaría-García, Carmen (2014) "Evaluative discourse and politeness in university students' communication through social networking sites". In Geoff Thompson, \& Laura Alba-Juez (eds.) Evaluation in Context. Amsterdam: John Benjamins. 387-411.

to claim common ground by means of the strategies 1,5 and 7 . Moreover, she conveys that $\mathrm{S}$ and $\mathrm{H}$ are cooperators and indicates that $\mathrm{S}$ knows H's wants and is taking them into account by asserting her concern for H's wants (strategy 9): “Eva was just there today helping to gut a house. It's pretty devastating stuff." The use of intensification in these utterances helps to increase the interest and sympathy with $\mathrm{H}$ (strategy 3 for claiming common ground). Both utterances can be considered indirect expressions of attitude. The first, can be considered an indirect judgement of social esteem, tenacity, by referring to a resolute behaviour: "Eva was just there today helping to gut a house" by means of appreciation (unbalanced composition). The second "It's pretty devastating stuff' is an indirect expression of affect, unhappiness by means of appreciation, negative reaction.

In the last two utterances, Eva produces another strategy (number 15) by fulfilling H's want for cooperation: "I'm also helping to collect school supplies, which is apparently needed; One of my friends is making another trip up there Monday." These literal acts of affect (satisfaction) express indirect tokens of judgement of social sanction, propriety (positive praise).

“@@ Insert SAN-TABLE-9 here”

\begin{tabular}{|l|l|l|}
\hline Instance & Positive politeness strategies & $\begin{array}{l}\text { Appraisal: } \\
\text { Types of attitude }\end{array}$ \\
\hline User (a). (Summons for help in an area devastated by floods) & \\
I like this (Click of & Claim common ground & \\
the "like" button by & 1. Notice, attend to H (his interest, & T-judgement, social \\
\hline
\end{tabular}


Santamaría-García, Carmen (2014) "Evaluative discourse and politeness in university students' communication through social networking sites". In Geoff Thompson, \& Laura Alba-Juez (eds.) Evaluation in Context. Amsterdam: John Benjamins. 387-411.

\begin{tabular}{|c|c|c|}
\hline Eva) & $\begin{array}{l}\text { wants, needs, goods) } \\
\text { Claim common attitude: } \\
\text { 5. Seek agreement } \\
\text { 7. Assert common ground } \\
\text { Convey that } \mathrm{S} \text { and } \mathrm{H} \text { are cooperators } \\
\text { Indicate } \mathrm{S} \text { knows H's wants and is } \\
\text { taking them into account }\end{array}$ & $\begin{array}{l}\text { sanction, } \\
\text { propriety (good } \\
\text { behaviour) } \\
\text { [Affect] }\end{array}$ \\
\hline $\begin{array}{l}\text { Eva was just there } \\
\text { today helping to gut } \\
\text { a house. }\end{array}$ & $\begin{array}{l}\text { Claim common ground } \\
\text { Convey } \mathrm{X} \text { is admirable, interesting: } \\
\text { 1. Notice, attend to H (his interest, } \\
\text { wants, needs, goods) } \\
\text { 3. Intensify interest to H } \\
\text { Claim common attitude: } \\
\text { 5. Seek agreement, } \\
\text { 7. Assert common ground } \\
\text { Convey that S and H are cooperators } \\
\text { Indicate } \mathrm{S} \text { knows H's wants and is } \\
\text { taking them into account } \\
\text { 9. Assert or presuppose S's knowledge } \\
\text { of and concern for H's wants }\end{array}$ & $\begin{array}{l}\text { T-judgement } \\
\text { [Appreciation] } \\
\text { Social esteem, } \\
\text { tenacity (resolute), } \\
\text { (positive, admire) }\end{array}$ \\
\hline $\begin{array}{l}\text { It's pretty } \\
\text { devastating stuff. }\end{array}$ & $\begin{array}{l}\text { Claim common ground } \\
\text { 3. Intensify interest to } \mathrm{H} \\
\text { Indicate } \mathrm{S} \text { knows H's wants and is } \\
\text { taking them into account } \\
\text { 9. Assert or presuppose } \mathrm{S} \text { 's knowledge }\end{array}$ & $\begin{array}{l}\text { T-affect } \\
\text { [Appreciation] } \\
\text { (Unhappy) }\end{array}$ \\
\hline
\end{tabular}


Santamaría-García, Carmen (2014) "Evaluative discourse and politeness in university students' communication through social networking sites". In Geoff Thompson, \& Laura Alba-Juez (eds.) Evaluation in Context. Amsterdam: John Benjamins. 387-411.

\begin{tabular}{|c|c|c|}
\hline & of and concern for H's wants & \\
\hline $\begin{array}{l}\text { I'm also helping to } \\
\text { collect school } \\
\text { supplies, which is } \\
\text { apparently needed; }\end{array}$ & $\begin{array}{l}\text { Claim common ground } \\
\text { Convey X is admirable, interesting: } \\
\text { 1. Notice, attend to H (his interest, } \\
\text { wants, needs, goods) } \\
\text { Claim common attitude: } \\
\text { 5. Seek agreement } \\
\text { 7. Assert common ground } \\
\text { Convey that S and H are cooperators } \\
\text { Indicate S knows H's wants and is } \\
\text { taking them into account } \\
\text { 9. Assert or presuppose S's knowledge } \\
\text { of and concern for H's wants } \\
\text { Fulfil H's want (for some X) } \\
\text { 15. Give gifts to H (goods, sympathy, } \\
\text { understanding, cooperation) }\end{array}$ & $\begin{array}{l}\text { T-judgement, } \\
\text { [Affect] } \\
\text { Social sanction, } \\
\text { propriety (positive } \\
\text { praise) }\end{array}$ \\
\hline $\begin{array}{l}\text { One of my friends is } \\
\text { making another trip } \\
\text { up there Monday. }\end{array}$ & $\begin{array}{l}\text { Claim common ground } \\
\text { Convey } \mathrm{X} \text { is admirable, interesting: } \\
\text { 1. Notice, attend to H (his interest, } \\
\text { wants, needs, goods) } \\
\text { Claim common attitude: } \\
\text { 5. Seek agreement } \\
\text { 7. Assert common ground } \\
\text { Convey that } \mathrm{S} \text { and } \mathrm{H} \text { are cooperators }\end{array}$ & $\begin{array}{l}\text { T-judgement } \\
\text { [Appreciation] } \\
\text { Social esteem, } \\
\text { tenacity (resolute), } \\
\text { (positive, admire) }\end{array}$ \\
\hline
\end{tabular}


Santamaría-García, Carmen (2014) "Evaluative discourse and politeness in university students' communication through social networking sites". In Geoff Thompson, \& Laura Alba-Juez (eds.) Evaluation in Context. Amsterdam: John Benjamins. 387-411.

\begin{tabular}{|l|l|l|}
\hline $\begin{array}{l}\text { Indicate S knows H's wants and is } \\
\text { taking them into account } \\
\text { 9. Assert or presuppose S's knowledge } \\
\text { of and concern for H's wants } \\
\text { 15. Give gifts to H (goods, sympathy, } \\
\text { understanding, cooperation) }\end{array}$ & \\
\hline
\end{tabular}

Table 9. Illustration for the correspondence between positive politeness strategies and appraisal resources

As a result of the analysis presented here, it seems that, in order to fulfil the three broad mechanisms for positive politeness mentioned above, speakers exploit appraisal resources to express attitude, (affect, judgement or appreciation), which allows them to evaluate and share the results of evaluative appreciations with their community.

\section{Conclusions}

The use of positive politeness strategies and appraisal resources for the expression of attitude are stimulated by the special context of IMI in the interaction on SNSs. These sites facilitate the establishment and maintenance of personal relations in communities of friends by means of several distinctive features such as their orientation to the interactional and interpersonal in a dialogic frame together with the fact that the whole community is connected by positive affective involvement and can be addressed simultaneously. These features trigger the use of attitudinal meanings and positive 
Santamaría-García, Carmen (2014) "Evaluative discourse and politeness in university students' communication through social networking sites". In Geoff Thompson, \& Laura Alba-Juez (eds.) Evaluation in Context. Amsterdam: John Benjamins. 387-411.

politeness, which occur frequently in the data. Attitude is expressed in a total of 248 of evaluative utterances in the one hundred turns analysed. It is mainly exploited for the expression of affect $(64.11 \%, n=159)$, with lower percentages for judgement $(21.77 \%$, $\mathrm{n}=54)$ and appreciation $(14.11 \%, \mathrm{n}=35)$. These meanings frequently intervene in the expression of positive politeness for the construction of common ground $(67 \%, n=117)$, conveying cooperation $(14.94 \%, \mathrm{n}=26)$ and fulfilling addressee's wants $(17.81 \%$, $n=31$ ), essential components for the management of interpersonal rapport among students. Affect is present in $57.45 \%(\mathrm{n}=104)$ of the 181 positive politeness strategies in the data, judgement in $22.09 \%(n=40)$ and appreciation in $16.57 \%(n=30)$.

The fact that the one hundred turns analysed contain 181 strategies of positive politeness (versus 2 instances of negative politeness), indicates the usefulness of SNSs as a medium in which users can satisfy their need for positive face. The results from the analysis of the combination of politeness strategies with attitudinal meanings shows that the users of SNSs rely heavily on the expression of attitude in order to build positive face for relational work, as a total of 174 (out of 181 positive politeness strategies) contain attitudinal meanings, which means $96.11 \%$ of them.

It is worth mentioning that the expression of affect and appreciation, frequently triggered by the "I like" button may convey an indirect meaning of judgement, contributing to build the systems of values for social sanction and social esteem in groups of friends and taking the responsibility for such judgements off the friends' shoulders. This might mean that users are more open to the expression of feelings and the appreciation of things but prefer to use more indirect ways to express judgements, thus avoiding the responsibility implicit in judgement of people's behaviour. The "I like" button provides a way for such avoidance. The productivity of the "like" button and emoticons to express attitude also helps to build solidarity among users by virtue of 
Santamaría-García, Carmen (2014) "Evaluative discourse and politeness in university students' communication through social networking sites". In Geoff Thompson, \& Laura Alba-Juez (eds.) Evaluation in Context. Amsterdam: John Benjamins. 387-411.

the two principles that serve to its construction according to appraisal theory, i.e. proliferation and contraction.

This article has suggested some areas of interest for further research with more data in order to describe the ways in which students' identities and personal relationships are shaped and realised by the expression of appraisal and politeness. This would throw light on the underlying systems of values of the group under study. The analysis of engagement and graduation, which have been beyond the scope of this paper, would also deepen our understanding of the role of appraisal in communication on SNSs.

\section{Acknowledgments}

This paper has been written while doing research for the project "Funciones Discursivas: La Evaluación en Distintos Tipos Textuales (FUNDETT), FFI2009-07308, sponsored by the Spanish Ministry of Science and Innovation and directed by Dr. Laura Alba Juez (UNED, Spain) <http://www.uned.es/proyectofundett/>.

I want to thank Geoff Thompson, Francisco Yus and Laura Alba Juez for valuable comments on earlier versions of this paper.

I also want to thank all the anonymous users who kindly contributed to the corpus of Facebook messages. Thanks also to my friends Danielle Kuehnel, Andreas Loizou, Michael O'Shea and Fiona Shelton for useful comments and observations from their Facebook data. 
Santamaría-García, Carmen (2014) "Evaluative discourse and politeness in university students' communication through social networking sites". In Geoff Thompson, \& Laura Alba-Juez (eds.) Evaluation in Context. Amsterdam: John Benjamins. 387-411.

\section{Works Cited}

Bednarek, Monika. 2008. Emotion Talk across Corpora. Houndmills/ New York: Palgrave Macmillan.

Bhatia, Vijay K. 2004. Worlds of Written Discourse: A Genre-Based View. London: Continuum.

Brown, Gillian and Yule, George. 1983. Discourse Analysis. Cambridge: Cambridge University Press.

Brown, Penelope and Levinson, Stephen. 1987. Politeness: Some Universals in Language Usage, $15^{\text {th }}$ edn. Cambridge: Cambridge University Press.

Carter, Ronald and Nash, Walter. 1990. Seeing through Language. Oxford: Blackwell. Channell, Joanna. 2000. “Corpus analysis of evaluative lexis.” In Evaluation in Text: Authorial Stance and the Construction of Disourse, Susan Hunston and Geoff Thompson (eds), 38-56. Oxford: Oxford University Press.

Denzin, Norman K. and Lincoln, Yvonna S.. 1994. "Introduction: Entering the field of qualitative research.” In Handbook of Qualitative Research, Norman Y. Denzin and Yvonna S. Lincoln (eds), 1-17. Thousand Oaks: Sage.

Eelen, Gino. 2001. A Critique of Polienesss Theories. St. Jerome: Manchester.

Eggins, Suzanne and Slade, Diana. 1997. Analysing Casual Conversation. London: Cassell.

Goffman, Erving. 1967. Interaction Ritual: Essays on Face to Face Behavior. Garden City: New York.

Halliday, Michael A. K. 2004 [1994/1985]. An Introduction to Functional Grammar. London: Edward Arnold. (Third edition revised by Matthiessen). 
Santamaría-García, Carmen (2014) "Evaluative discourse and politeness in university students' communication through social networking sites". In Geoff Thompson, \& Laura Alba-Juez (eds.) Evaluation in Context. Amsterdam: John Benjamins. 387-411.

Hoey, Michael. 2000. "Persuasive Rhetoric in Linguistics: A Stylistic Study of Some Features of the Language of Noam Chomsky." In Evaluation in Text. Authorial Stance and the Construction of Discourse, Susan Hunston and Geoff Thompson (eds), 28-37. Oxford: Oxford University Press..

Hunston, Susan and Thompson, Geoff (eds.). 2000.Evaluation in Text. Authorial Stance and the Construction of Discourse. Oxford: Oxford University Press.

Lakoff, Robin \& Sachiko Ide, S. 2005. Broadening the Horizons of Linguistic Politeness. Amsterdam/Philadelphia: John Benjamins.

Locher, Miriam and Watts, Richard J. 2005. "Politeness theory and relational work." Journal of Politeness Research 1 (1): 9-33.

Martin, James R. 2000. "Beyond Exchange: APPRAISAL Systems in English.” In Evaluation in Text. Authorial Stance and the Construction of Discourse, Susan Hunston and Geoff Thompson (eds), 142-175. Oxford: Oxford University Press.

Martin, James R. and White, Peter R. R. 2005. The Language of Evaluation. Appraisal in English. New York: Palgrave Macmillan.

Martínez Ana M. and Wartmann, Katherine L. 2009. Online Social Networking on Campus: Understanding what Matters in Student Culture. Routledge: New York.

Mills, Sarah. 2003. Gender and Politeness. Cambridge: Cambridge University Press.

O’Donnell, Michael. 2011. UAM Corpus Tool 2.7. Madrid: UAM.

O’Donnell, Michael. 2008. "The UAM CorpusTool: Software for corpus annotation and exploration." Proceedings of the XXVI Congreso de AESLA. Almeria, Spain, 3-5 April 2008.

Santamaría-García, Carmen. 2005. La Negociación de Acuerdo en la Conversación Coloquial. Estudio Contrastivo: Español-Inglés. (CD ROM). (Doctoral 
Santamaría-García, Carmen (2014) "Evaluative discourse and politeness in university students' communication through social networking sites". In Geoff Thompson, \& Laura Alba-Juez (eds.) Evaluation in Context. Amsterdam: John Benjamins. 387-411.

dissertation). Madrid: Universidad Complutense de Madrid. Accessed February 2011. 〈http://eprints.ucm.es/5477/>.

Santamaría-García, Carmen. 2011. "Bricolage assembling: $C L, C A$ and $D A$ to explore the negotiation of agreement in English and Spanish conversation.” International Journal of Corpus Linguistics. 16: 3: 346-371.

Santamaría-García, Carmen. Forthcoming. "A compelling need to evaluate: social networking sites as tools for the expression of affect, judgment and appreciation.” In Intercultural Pragmatics, Istvan Kecskes and Jesús RomeroTrillo (eds), Berlin: Mouton de Gruyter.

Sinclair, John, McH. and Malcolm Coulthard. 1975. Towards an Analysis of Discourse. Oxford: Oxford University Press.

Spencer-Oatey, Helen. 2000. Culturally Speaking. London, New York: Continuum. Thompson, Geoff. 2011. "Russian Dolls, Target-VALUE mismatches, and Evaluation." Plenary at Int-eval, International Workshop on the Evaluative Function of Language: Evaluation across Text-Types and Cultures. Madrid: UNED.

Thompson Geoff and Hunston, Susan. 2000. "Evaluation: an introduction." In Evaluation in Text: Authorial Stance and the Construction of Disourse, Susan Hunston and Geoff Thompson (eds), 1-28. Oxford: Oxford University Press, 2000.Tsui, Amy B. M. 1994. English Conversation. Oxford: Oxford University Press.

Watts, Richard. 2003. Politeness. Cambridge: Cambridge University Press.

Watts, Richard, Ide, Sachiko and Konrad Ehlich. 2005. Politeness in Language. Berlin: Mouton de Gruyter.

Wharton, Tim. 2009. Pragmatics and Non-verbal Communication. Cambridge: Cambridge University Press. 
Santamaría-García, Carmen (2014) "Evaluative discourse and politeness in university students' communication through social networking sites". In Geoff Thompson, \& Laura Alba-Juez (eds.) Evaluation in Context. Amsterdam: John Benjamins. 387-411.

Yus, Francisco. 2001. "Ciberpragmática: entre la compensación y el desconcierto.”

http://congresosdelalengua.es/valladolid/ponencias/nuevas_fronteras_del_espanol/4_len

gua_y_escritura/yus_f.htm. Congreso Internacional de la Lengua Española. Accessed 15 September 2011.

Yus, Francisco. 2011. Cyberpragmatics. Amsterdam: Benjamins.

\section{BIOGRAPHICAL NOTE}

Carmen Santamaría-García, received a European $\mathrm{PhD}$ in Linguistics from Complutense University, Madrid. She is currently a tenured Professor of Linguistics at Alcalá University, Madrid. Her teaching includes linguistics, pragmatics, discourse analysis and methodology at undergraduate and postgraduate levels. These are also her areas of research together with corpus linguistics and computer-mediated communication. She participates in several research projects and has publications in books and academic journals. Her latest work, illustrating the combination of corpus linguistics, conversation analysis and discourse analysis in what she calls 'bricolage research methodology' has recently appeared in the International Journal of Corpus Linguistics, (John Benjamins). 